\title{
Rancang Bangun Sistem Informasi Pengelolaan Surat Masuk dan Surat Keluar Berbasis Website pada Setum Polda Bali
}

\section{Ni Luh Putu Putri Vera Handayani ${ }^{1^{*}}$, I Nyoman Tri Anindia Putra ${ }^{2}$}

${ }^{12}$ Jurusan Teknik Informatika STMIK STIKOM Indonesia

\section{A R T I C L E I N F O}

Article history:

Received 19 April 2019

Received in revised form 10 May 2019

Accepted 12 June 2019

Available online 25 July

2019

\section{Kata Kunci:}

Sistem Informasi,

Pengelolaan Surat, Berbasis Web

Keywords:

Information Systems, Mail

Management, Web Based

\begin{abstract}
A B S T R A K
Setum Polda Bali merupakan salah satu bagian dari instansi pemerintah yang melayani proses pengelolaan surat masuk dan keluar yang ada di Polda Bali. Pada Setum Polda Bali pengelolaan surat masuk dan keluar masih dilakukan secara konvensional yang masih memiliki beberapa kelemahan, seperti memerlukan waktu yang lama dalam pencarian data surat serta penyampaian informasi surat yang lambat karena terbatasnya tenaga kerja pada Setum Polda Bali. Tujuan dilakukan penelitian ini adalah untuk membangun sebuah sistem informasi berbasis komputer yang dapat membantu pegawai dalam pengelolaan surat masuk dan keluar serta dapat memberikan kemudahan dalam pencarian dan penyampaian informasi surat. Metode pengumpulan data yang digunakan pada penelitian ini adalah metode primer serta metode sekunder. Sistem informasi pengelolaan surat masuk dan keluar yang telah dibangun, menunjukan hasil bahwa sistem ini mampu menyelesaikan pelaksanaan proses pengelolaan dan pelaporan surat dengan efektif serta efisien dalam penyampaian informasi surat pada Setum Polda Bali.
\end{abstract}

\section{A B S T R A C T}

Setum Polda Bali is one part of government agencies that serve the process of managing incoming and outgoing mail in Polda Bali. General Secretariat incoming and outgoing mail management still done conventionally which still has some weaknesses, such as requiring a long time in the search for letter data and submission of letter information which is slow due to the limited workforce at the Setum Polda Bali. The purpose of this research is to build a computer-based information system that can assist employees in managing incoming and outgoing mails and can provide convenience in searching and delivering mail information. Data collection methods used in this study are primary methods and secondary methods. The incoming and outgoing mail management information system that has been built shows the results that this system is able to complete the process of managing and reporting letters effectively and efficiently in delivering letter information to Setum Polda Bali.

\footnotetext{
* Corresponding author.

E-mail addresses: niluhputrivera@gmail.com (Ni Luh Putu Putri Vera Handayani)
} 


\section{Pendahuluan}

Dalam suatu instansi atau perusahaan, pengelolaan surat merupakan salah satu kegiatan atau pekerjaan yang rutin dilakukan. Pengelolaan surat merupakan suatu proses untuk mengatur dan menyusun surat-surat yang diterima dan dikeluarkan oleh instansi, yang berguna untuk penyampaian informasi dengan baik kepada pihak yang dituju. Pengelolaan surat harus dilakukan dengan tepat agar surat-surat yang diterima dan dikeluarkan dapat tersusun secara rapi serta mudah dalam pencarian informasi surat. Bagi instansi pemerintah atau swasta, penerapan pengelolaan surat harus dilaksanakan karena dapat mempermudah instansi dalam proses penyampaian informasi dengan baik kepada pihak yang dituju. Salah satu instansi pemerintah yang menerapkan proses pengelolaan surat, yaitu Sekretariat Umum (Setum) Polda Bali.

Setum Polda Bali merupakan instansi pemerintah yang tidak lepas dari kegiatan pengelolaan surat. Pengelolaan surat pada intansi ini meliputi kegiatan pengelolaan surat masuk dan surat keluar. Surat masuk pada instansi ini adalah surat-surat yang diterima dari perorangan, organisasi atau lembaga, perusahaan dan instansi, sedangkan surat keluar pada instansi ini adalah surat-surat yang dibuat atau dikeluarkan untuk ditujukan kepada pihak lain. Surat masuk dan surat keluar pada Setum Polda Bali memiliki sifat surat atau klasifikasi surat yang dapat digolongkan menjadi surat biasa, surat pribadi, surat rahasia, undangan, surat keputusan, surat telegram, surat telegram rahasia, surat edaran, surat ijin, surat perintah dan majalah atau buku. Proses pengelolaan surat pada Setum Polda Bali masih dilakukan secara konvensional, yakni surat masuk yang ditujukan untuk instansi diterima oleh Urkanpos (Urusan Kantor Pos) kemudian dipilah sesuai dengan bagian-bagian yang dituju, selanjutnya surat masuk dicatat pada sebuah buku ekspedisi yang akan diletakan pada loker sesuai dengan masing-masing bagian. Apabila surat ditujukan kepada Kapolda atau Wakapolda, surat tersebut kemudian dicatat pada buku agenda masuk serta membuat disposisi surat yang akan didistribusikan kepada pejabat yang diberi wewenang. Pencatatan surat masuk ke buku agenda masuk dan mendisposisikan surat dilakukan oleh Binsettakah (Pembinaan kesekretariatan dan tata naskah). Begitu pula dalam penanganan surat keluar pada Setum Polda Bali yang ditangani oleh Renmin (Perencanaan dan Administrasi) yang diawali dengan membuat rancangan surat yang akan dikirim, kemudian memeriksa kembali rancangan surat tersebut untuk mengecek kebenarannya. Apabila surat sudah benar dan disetujui, selanjutnya surat diberikan nomor surat keluar kemudian surat dikirim melalui fax atau kantor pos. Berdasarkan hasil wawancara yang didapatkan dari salah satu pegawai Setum, pada instansi ini dapat menerima surat masuk 100 sampai 150 surat dalam sehari, sedangkan pembuatan surat keluar pada instansi ini dapat membuat surat keluar 10 sampai 30 surat dalam sehari. Dalam melakukan proses pengelolan surat pada Setum, Setum memiliki 10 tenaga kerja yang bertugas untuk melaksankan tugas pengelolaan surat. Jumlah tenaga kerja yang terdapat pada Setum saat ini kurang memadai dalam menyelesaikan tugas pengelolaan surat. Hal itu disebabkan ketika salah satu pegawai Setum harus mengantarkan surat ke bagian atau pejabat yang dituju, maka pegawai Setum harus meninggalkan sementara tugas yang dilaksanakan sebelumnya sehingga pekerjaan sebelumnya yang harus diselesaikan menjadi tertunda. Proses pengelolaan surat yang masih dilakukan secara konvesional ini perlu diadakan perbaikan karena dalam proses yang berjalan saat ini memiliki beberapa kelemahan, seperti memerlukan waktu yang lama dalam pencarian informasi surat karena pencarian data dilakukan dengan cara memeriksa satu per satu surat dengan banyaknya jumlah surat yang tercatat pada buku agenda serta pengelolaan dan penyampaian informasi surat yang lambat karena terbatasnya tenaga kerja pada Setum Polda Bali.

Untuk mengatasi masalah tersebut maka diperlukan sebuah sistem informasi berbasis komputer yang dapat meminimalisir permasalahan yang sedang terjadi. Sistem informasi pengelolaan surat masuk dan surat keluar akan dibangun berbasis web karena perkembangan teknologi saat ini berpengaruh pada setiap kegiatan instansi sehingga pegawai dituntut untuk menyesuaikan kemampuan dengan kemajuan yang ada. Selain menyesuaikan perkembangan teknologi, tersedianya perangkat keras seperti Personal Computer (PC) dan printer yang disediakan oleh Setum Polda Bali dapat mendukung pengoperasian sistem informasi pengelolaan surat dengan mudah. Sistem informasi pengelolaan surat yang dibangun akan memiliki beberapa fungsi, seperti mengelola surat masuk dan surat keluar, mengelola laporan surat masuk dan surat keluar serta laporan disposisi surat masuk. Dengan adanya sistem informasi berbasis komputer ini, diharapkan dapat membantu Setum Polda Bali dalam melaksanakan proses pengelolaan surat serta dapat memberikan kemudahan dalam pencarian dan penyampaian informasi surat.

Berdasarkan uraian diatas, maka penulis membuat penelitian yang berjudul "Rancang Bangun Sistem Informasi Pengelolaan Surat Masuk dan Surat Keluar Berbasis Website pada Setum Polda Bali”. 


\section{Metode}

Pengumpulan data merupakan hal yang penting dilakukan sebelum melakukan penelitian. Dengan adanya pengumpulan data dapat memperoleh informasi yang dibutuhkan serta mempermudah dalam pengerjaan laporan penelitian ini. Pengumpulan data dapat dilakukan dengan cara mencari dan mengumpulkan data-data yang diperlukan untuk menganalisis kebutuhan sistem yang digunakan dalam perancangan sistem yang akan dibangun. Metode yang dipakai dalam pengumpulan data ini adalah metode primer dan sekunder.

\section{Metode Primer}

Metode yang pertama digunakan adalah metode primer. Metode primer dilakukan dengan mengumpulkan data yang diperoleh secara langsung dari Setum Polda Bali. Proses pengumpulan data primer dilakukan dengan dua tahap seperti wawancara dan observasi. Pelaksanaan tahap pertama metode primer adalah wawancara. Wawancara dilakukan langsung dengan Ibu IGA.A Sugiasih selaku Kaurrenmin di Setum Polda Bali. Wawancara dilakukan dengan mengajukan pertanyaan-pertanyaan, seperti menanyakan bagaimana alur proses pengelolaan surat serta kendala-kendala yang dihadapi dalam proses pengelolaan surat di Setum Polda Bali. Adapun hasil yang diperoleh dalam proses wawancara, yaitu mendapatkan informasi mengenai alur proses pengelolaan surat di Setum Polda Bali serta kendala yang dihadapi, yaitu terbatasnya tenaga kerja pada Setum Polda Bali membuat pengelolaan surat menjadi terhambat dan tidak tepat waktu dalam menyelesaikan tugas.

Tahap metode primer selanjutnya adalah observasi. Observasi yang dilakukan pada penelitian ini adalah observasi langsung ke lapangan dengan mengamati alur proses yang sedang berjalan pada proses pengelolaan surat pada instansi ini. Dari proses pengamatan tersebut penulis memperoleh informasi bagaimana proses pengelolaan surat pada instansi ini berlangsung, yaitu surat masuk yang diterima kemudian disortir sesuai dengan bagian-bagian yang dituju kemudian dicatat pada sebuah buku ekspedisi yang akan diletakan pada loker sesuai dengan masing-masing bagian. Apabila surat ditujukan kepada Kapolda atau Wakapolda surat dicatat pada buku agenda surat masuk dan membuat disposisi surat. Setelah membuat disposisi surat, kemudian surat tersebut didistribusikan kepada pegawai bagian atau pejabat yang diberi wewenang. Dalam penanganan surat keluar pada Setum Polda Bali, diawali dengan membuat rancangan surat, kemudian surat diperiksa kembali untuk memeriksa kebenarannya. Apabila surat sudah benar dan disetujui selanjutnya, surat diberikan nomor surat keluar dan surat dikirim melalui fax atau kantor pos.

\section{Metode Sekunder}

Setelah melakukan tahap metode primer, kemudian dilanjutkan dengan tahap metode sekunder. Pengumpulan data dengan metode sekunder merupakan teknik pengumpulan data yang diperoleh secara tidak langsung dari objek yang diteliti. Pengumpulan data yang diperloleh secara tidak langsung seperti data-data yang bersumber dari buku, jurnal, gambar, serta dokumen-dokumen milik instansi yang berhubungan dengan penelitian ini. Tahap metode sekunder diawali dengan tahap metode kepustakaan. Metode kepustakaan merupakan salah satu teknik pengumpulan data yang dilakukan dengan memperoleh informasi dan teori-teori dari buku, jurnal, majalah serta dokumen-dokumen pendukung yang berkaitan dengan penelitian ini. Pada Penelitian ini, penulis mendapatkan teori-teori yang diperlukan dalam penyusunan laporan, seperti teori sistem, informasi, sistem informasi, website, analisis dan perancangan sistem, data flow diagram, ERD, database, HTML, CSS, PHP, javascript, MySQL, surat, disposisi serta penelitian terdahulu yang dapat dijadikan evaluasi dari penelitian yang dilakukan penulis.

Tahap setelah melakukan studi pustaka, kemudian dilanjutkan dengan tahap dokumentasi. Dokumentasi merupakan teknik pengumpulan data dengan cara mencari dan mengumpulkan berbagai macam dokumen antara lain buku, majalah dan berkas-berkas yang berkaitan dengan pengelolaan surat dalam bentuk foto atau gambar. Hasil dari pengumpulan data yang diperoleh dengan metode dokumentasi pada instansi ini berupa data contoh pencatatan surat masuk dan surat keluar, pencatatan disposisi surat serta pencatatan agenda surat.

\section{a) Hasil dan pembahasan}

Analisis Dan Perancangan Sistem Analisis

Dalam menganilisis dan merancang sistem informasi pengelolaan surat, ada beberapa hal yang perlu dilakukan seperti menganilisis sistem yang sedang berjalan dan sistem yang diajukan, menganalisis kebutuhan sistem serta melakukan perancangan sistem. 


\section{Analisis Sistem yang Berjalan}

Tahap pertama yang dilakukan dalam merancang sistem ini adalah tahap menganalisis sistem yang sedang berjalan. Analisa sistem yang sedang berjalan merupakan hal penting dilakukan oleh penulis untuk mengetahui permasalahan yang terjadi pada sistem tersebut, baik menganalisa dari cara kerja sistem ataupun penerapannya. Berdasarkan hasil observasi yang dilakukan penulis, dapat digambarkan mekanisme kerja sistem pengelolaan surat pada Setum Polda Bali yang diawali dari proses pengelolaan surat masuk yang sedang berjalan dimulai dari Kaurkanpos menerima surat masuk kemudian melakukan penyortiran surat sesuai dengan bagian yang dituju setelah itu, surat dicatat pada sebuah buku ekspedisi. Setelah surat dicatat di buku ekspedisi, surat dapat diberikan ke bagian Binsettakah. Bagian Binsettakah membuka sampul surat serta mencatat surat masuk ke buku agenda surat masuk. Surat masuk yang sudah dicatat pada buku agenda selanjutnya, bagian Binsettakah membuat disposisi surat dan mendistribusikan surat tersebut kepada pegawai bagian atau pejabat yang berwenang. Bagian Binsettakah kemudian merekap data surat masuk dan membuat laporan surat masuk yang akan diarsip serta diberikan kepada Kepala Setum.

Sedangkan untuk proses pengelolaan surat keluar dimulai dari bagian Renmin membuat surat keluar kemudian surat tersebut diberikan kepada Kepala Setum untuk memeriksa kebenaran dari surat tersebut. Apabila surat sudah benar, surat dapat ditandatangani oleh Kepala Setum dan surat yang sudah ditandatangani, selanjutnya diberikan nomor surat keluar dan dicatat pada sebuah buku agenda keluar. Surat keluar yang sudah mendapatkan nomor surat dan sudah dicatat pada buku agenda keluar, selanjutnya surat tersebut digandakan. Penggandaan surat dilakukan karena surat asli akan dikirim kepada kantor pos untuk dikirim dan surat duplikat akan disimpan atau diarsip. Setelah melakukan penggandaan surat keluar, surat keluar yang tercatat pada buku agenda keluar kemudian direkap untuk membuat laporan surat keluar. Laporan surat keluar kemudian diarsip dan diberikan kepada Kepala Setum. Proses pengelolaan surat masuk dan surat keluar yang sedang berjalan pada Setum Polda Bali dapat digambarkan dalam bentuk dokument flow diagram pada gambar berikut:

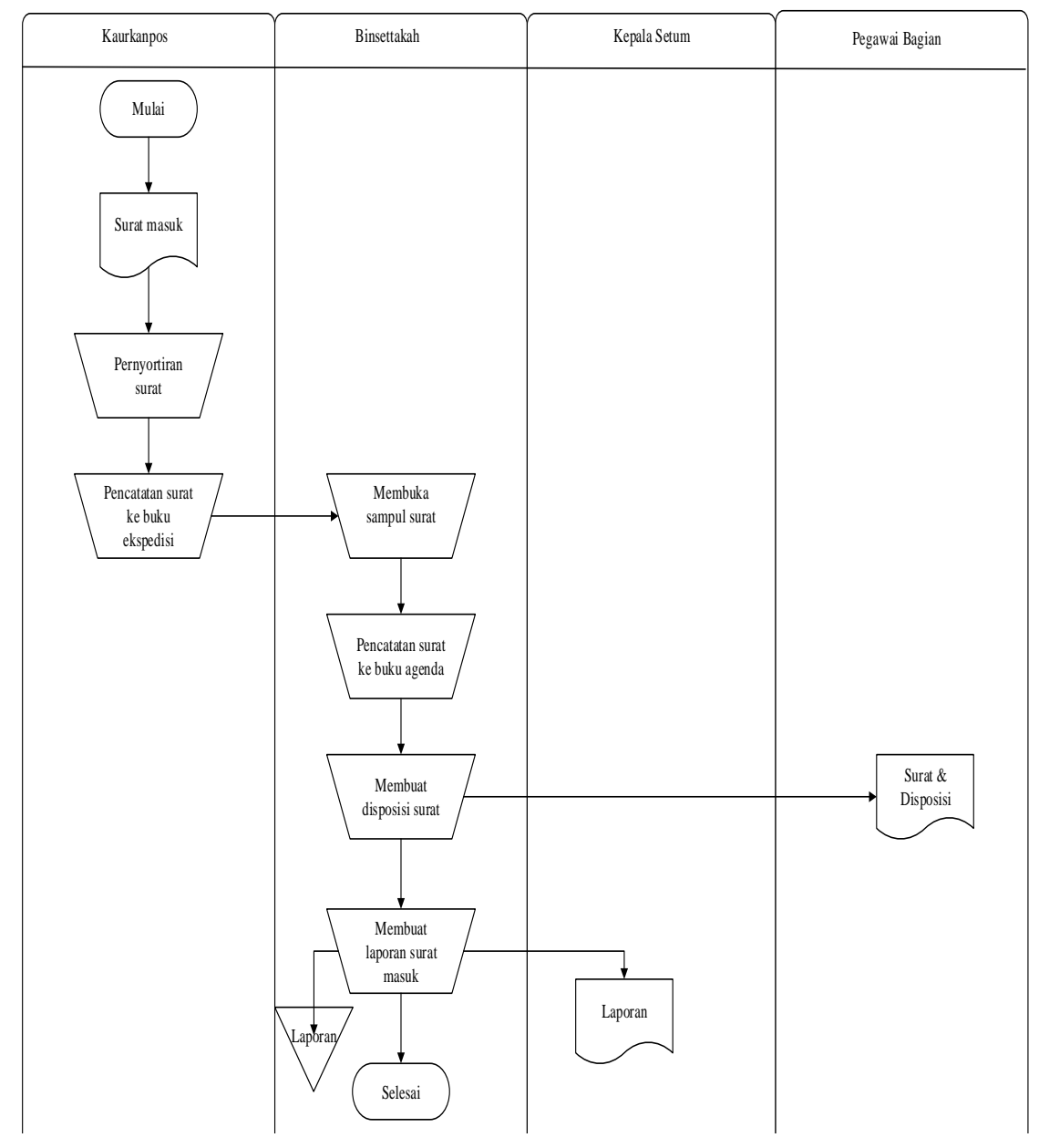

Gambar 1. Dokument Flow Diagram Pengelolaan Surat Masuk 


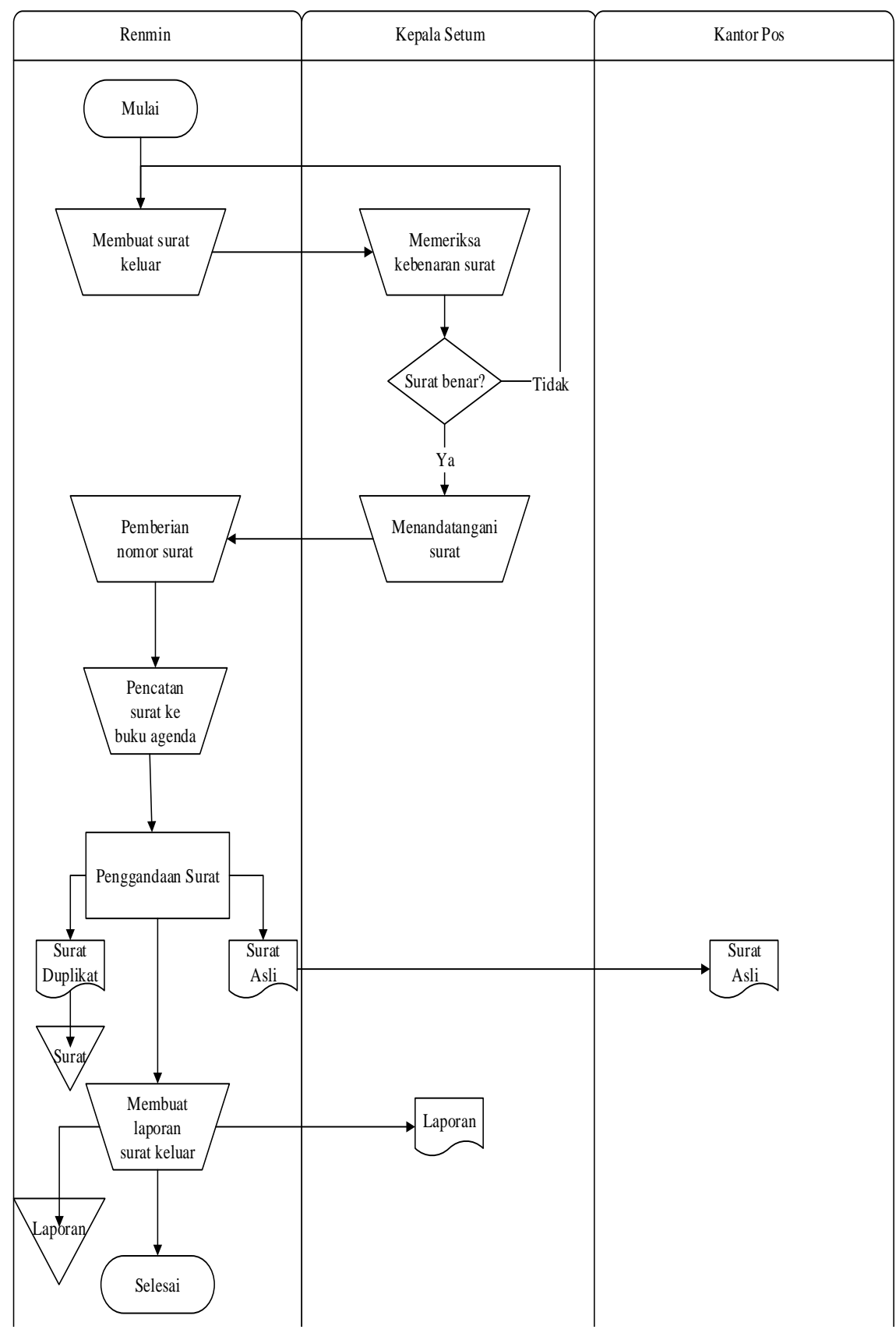

Gambar 2. Dokument Flow Diagram Pengelolaan Surat Keluar

Dari proses pengelolaan surat masuk dan keluar yang berjalan saat ini perlu diadakan perbaikan dikarenakan dalam proses saat ini memiliki beberapa kelemahan yaitu membutuhkan waktu yang lama dalam pencarian data karena pencarian data surat dilakukan dengan cara memeriksa satu per satu surat dengan banyaknya jumlah surat yang tercatat pada buku agenda surat serta apabila terjadi kesalahan penulisan isi surat dan ketidakbenaran isi surat dalam pembuatan surat keluar maka pegawai mencetak ulang surat tersebut sehingga membutuhkan biaya yang banyak dalam proses pembuatan surat.

\section{Analisis Sistem Yang Berjalan}

Setelah melakukan analisis sistem yang sedang berjalan, tahap selanjutnya yang dilakukan adalah tahap analisis sistem yang diajukan. Analisis sistem yang diajukan bertujuan untuk merancangan suatu sistem yang dapat meminimalisir serta mengatasi permasalahan yang terjadi. Sistem yang dirancang ini menggunakan komputer serta diaplikasikan ke dalam suatu sistem informasi pengelolaan surat masuk dan surat keluar yang berbasis website. Tujuan dari perancangan sistem ini adalah menghasilkan suatu sistem informasi pengelolaan surat yang efektif dalam menyelesaikan proses pengelolaan surat Analisis Sistem Yang Diajukan 
Berdasarkan hasil analisis yang sebelumnya telah dilakukan, maka penulis mengajukan suatu rancangan sistem yang dapat meminimalisir serta mengatasi permasalahan yang terjadi. Sistem yang dirancang ini menggunakan komputer serta diaplikasikan ke dalam suatu sistem informasi pengelolaan surat masuk dan surat keluar yang berbasis website. Tujuan dari perancangan sistem ini adalah menghasilkan suatu sistem informasi pengelolaan surat yang efektif dalam menyelesaikan proses pengelolaan surat serta efisien dalam pencarian dan penyampaian informasi surat dengan tepat waktu.

Analisis Kebutuhan Sistem

Analisis kebutuhan sistem dibagi menjadi 2 yaitu analisis kebutuhan fungsional dan kebutuhan non-fungsional. Analisis kebutuhan fungsional dari sistem informasi pengelolaan surat masuk dan surat keluar pada Setum Polda Bali mencakup beberapa hal seperti Pengguna dapat melakukan login dengan data user yang telah didaftarkan untuk dapat mengakses sistem, sistem dapat melakukan pengelolaan data master, yakni data user, data bagian serta data sifat surat, sistem mampu mengelola surat masuk dan surat keluar, melihat status surat, approve surat, mendisposisikan surat, serta menampilkan dan mencetak laporan surat dan disposisi surat. Adapun elemen-elemen yang terlibat dalam sistem antara lain Pegawai Setum, Pegawai bagian, Kepala Setum serta Pengirim surat.

Selanjutnya tahap menganalisis Kebutuhan Non-Fungsional. Analisis kebutuhan non-fungsional dari sistem informasi pengelolaan surat masuk dan surat keluar berbasis website pada Setum Polda Bali mencakup beberapa hal yang dilakukan dalam perancangan sistem ini, perangkat keras yang diperlukan adalah Processor Intel Core $^{\mathrm{TM}}$ i5 CPU @ $2.20 \mathrm{GHz}$, Memory RAM 4.00 GB serta VGA Intel ${ }^{\circ}$ HD Graphics 5500. Perangkat Lunak (Software) yang diperlukan dalam perancangan sistem ini, perangkat lunak yang dibutuhkan adalah Sybase® PowerDesigner 15.2, Balsamiq Mockups 3, Visio 2013 dan XAMPP Control Panel v3.2.1.

\section{Perancangan Sistem}

Perancangan sistem pada penelitian ini dijelaskan melalui event list serta data flow diagram (DFD) yang diterapkan pada sistem informasi pengelolaan surat.

Event List

Event list merupakan daftar kejadian yang terjadi dalam lingkungan suatu sistem dan mempunyai hubungan yang diberikan oleh sistem. Berdasarkan hasil analisis dari sistem yang akan dibangun maka dapat dijabarkan event list pada Rancang Bangun Sistem Informasi Pengelolaan Surat Masuk dan Surat Keluar berbasis website pada Setum Polda Bali sebagai berikut:
1. Login
2. Mengelola Data user
2.1 Tambah data user
2.2 Ubah data user
2.3 Cari data user
3. Mengelola Data Bagian
3.1 Tambah data bagian
3.2 Ubah data bagian
3.3 Cari data bagian
4. Mengelola Data Sifat Surat
4.1 Tambah Data Sifat Surat
4.2 Ubah Data Sifat Surat
4.3 Cari Data Sifat Surat
5. Mengelola Data Surat
5.1 Mengelola Surat Masuk
5.1.1 Tambah Data Surat Masuk
5.1.2 Ubah Data Surat Masuk
5.1.3 Hapus Data Surat Masuk
5.1.4 Cari Data Surat Masuk
5.2 Mengelola Surat Keluar
5.2.1 Tambah Data Surat Keluar
5.2.2 Ubah Data Surat Keluar
5.2.3 Hapus Data Surat Keluar
5.2.4 Cari Data Surat Keluar
6. Mengelola Laporan
6.1 Laporan Surat Masuk
6.2 Laporan Surat Keluar 


\subsection{Laporan Disposisi Surat Masuk 6.4 Laporan Grafik Data Surat}

(DFD) Data flow diagram Level 0

Data flow diagram ini merupakan rancangan sistem yang digambarkan dengan aliran arus data yang bergerak pada sebuah sistem. Dalam rancangan pembuatan sistem informasi pengelolaan surat masuk dan surat keluar berbasis website pada Setum Polda Bali, menjelaskan mengenai apa yang dapat dilakukan oleh Pegawai Setum, Pegawai bagian, Kepala Setum serta Pengirim surat pada sistem informasi ini.

Data flow diagram (DFD) Level 0 menjelaskan aliran arus data yang lebih jelas dari diagram konteks. Pada gambar 3. menggambarkan Data flow diagram (DFD) Level 0 sistem informasi pengelolaan surat ini memiliki beberapa proses, yaitu login, mengelola data user, mengelola data bagian, mengelola data sifat surat, mengelola data surat serta mengelola laporan. Data flow diagram (DFD) Level 0 sistem informasi pengelolaan surat dimulai dari proses login yang dapat dilakukan oleh Pegawai Setum, Kepala Setum serta Pegawai bagian. Proses selanjutnya yaitu mengelola data user. Pada proses mengelola data user dapat dilakukan oleh Pegawai Setum, Pegawai bagian dan Kepala Setum. Semua data-data user yang ditambahkan disimpan dalam data store data user. Setelah itu dilanjutkan ke proses mengelola data bagian.

Dalam proses mengelola data bagian hanya dapat dilakukan oleh Pegawai Setum. Semua data-data bagian yang ditambahkan disimpan dalam data store data bagian. Proses selanjutnya adalah mengelola data sifat surat. Proses mengelola data sifat surat hanya dapat dilakukan oleh Pegawai Setum. Data-data sifat surat yang ditambahkan kemudian disimpan dalam data store data sifat surat. Selanjutnya proses mengelola data surat. Pada proses data surat ini dapat dilakukan oleh Pegawai Setum, Pegawai bagian, Kepala Setum serta Pengirim surat. Semua data surat masuk yang telah ditambahkan kemudian disimpan dalam data store data surat masuk dan data-data surat keluar disimpan dalam data store data surat keluar sedangkan data-data disposisi masuk disimpan dalam data store data disposisi.

Proses akhir dari Data flow diagram (DFD) Level 0 sistem informasi pengelolaan surat yaitu mengelola laporan. Pada proses mengelola laporan ini dapat dilakukan oleh Pegawai Setum dan Kepala Setum. Data-data yang dihasilkan dari laporan ini adalah data-data yang diperoleh dari data store data surat masuk dan data store data surat keluar serta data store data disposisi. 


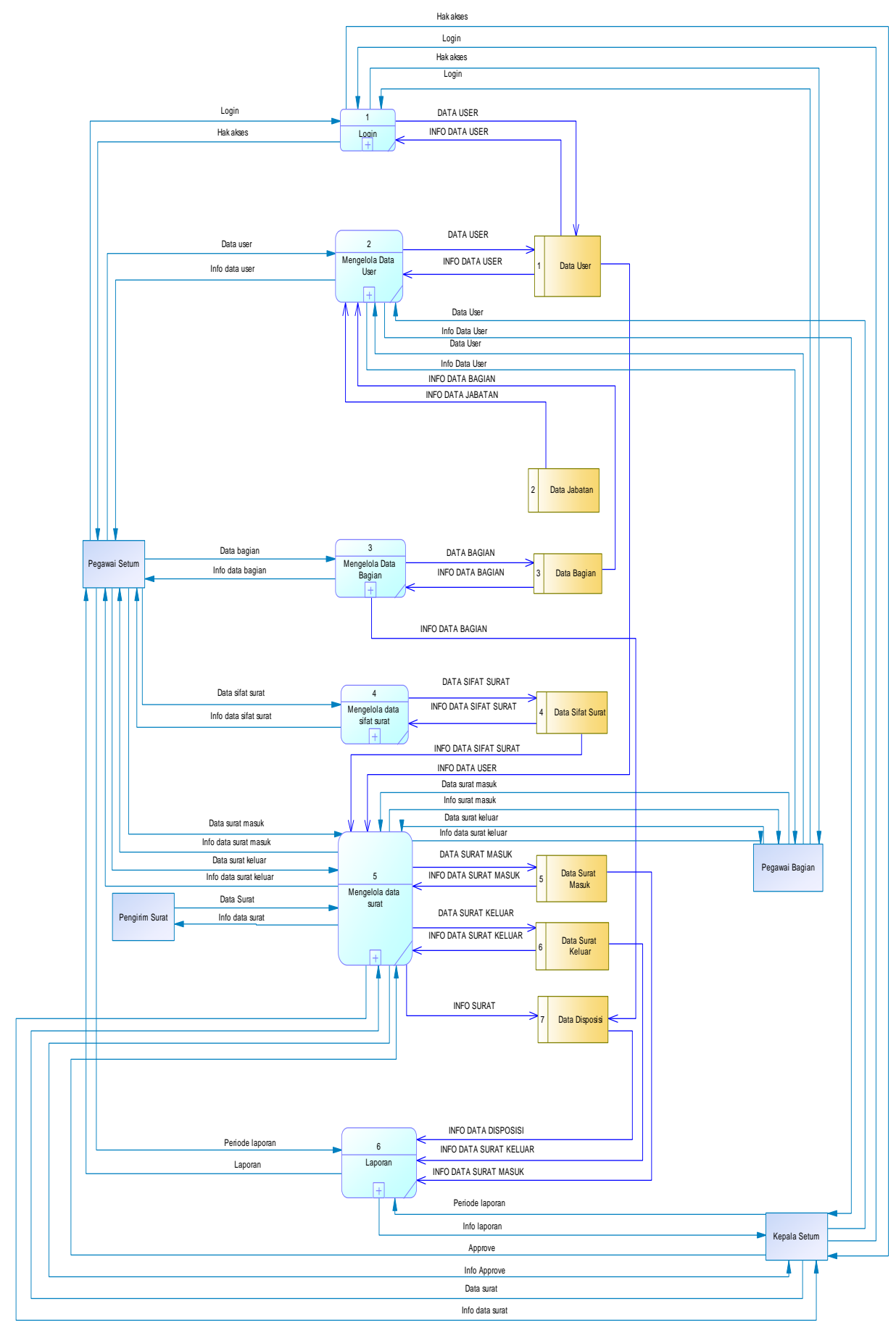

Gambar 3. DFD Level 0 Sistem Informasi Pengelolaan Surat

Implementasi dan Pembahasan

Implementasi merupakan tahapan yang dilakukan setelah melakukan analisis dan perancangan antarmuka terhadap sistem yang dibangun, kemudian diterapkan dengan menggunakan perangkat keras dan perangkat lunak sesuai dengan analisis kebutuhan sistem. Implementasi dilakukan dengan tujuan untuk menerapkan perancangan antarmuka yang telah dibangun dan menjelaskan komponen, fungsi serta proses pada sistem. Dalam implementasi pada Sistem Informasi Pengelolaan Surat Masuk dan Surat Keluar memiliki 4 hak akses yaitu Kepala Setum, Pegawai Setum, Pegawai Bagian dan Pengirim Surat. Berikut ini adalah implementasi antarmuka dan beberapa proses pada Sistem Informasi Pengelolaan Surat Masuk dan Surat Keluar Berbasis Website Pada Setum Polda Bali. 


\section{Halaman Login}

Halaman login pada merupakan tampilan awal yang muncul sebelum menuju ke halaman utama. Halaman login pada umumnya terdapat pada sebuah sistem informasi yang berfungsi untuk membatasi pengguna yang memiliki hak akses untuk menggunakan sistem. Pada halaman login pengguna sistem wajib mengisi username dan password untuk mengakses halaman utama. Halaman login juga terdapat sebuah link untuk mengecek status surat yang dapat diakses oleh pengirim surat.

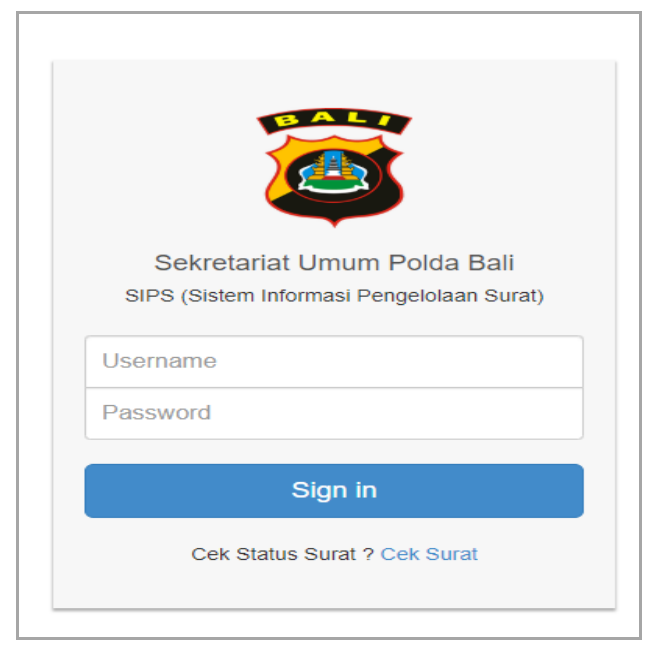

Gambar 4. Halaman Login

Halaman Hak Akses Kepala Setum

Halaman hak akses Kepala Setum merupakan halaman yang muncul ketika Kepala Setum telah melakukan proses login terlebih dahulu. Halaman ini, menampilkan beberapa pilihan menu, seperti beranda, data user, riwayat surat, surat masuk, surat keluar serta laporan. Tampilan awal yang muncul pada halaman hak akses Kepala Setum adalah beranda yang menampilkan grafik jumlah data surat serta notifikasi jumlah surat masuk dan surat keluar. Pada menu data user, Kepala Setum dapat menambah, mengubah dan melihat data user. Selanjutnya menu surat masuk dan surat keluar, menu ini menampilkan data surat masuk dan keluar yang telah ditambahkan oleh pegawai yang memerlukan persetujuan dari Kepala Setum. Untuk pengelohan laporan, Kepala Setum dapat mencari serta mencetak laporan surat dan disposisi sesuai dengan periode yang ditentukan.

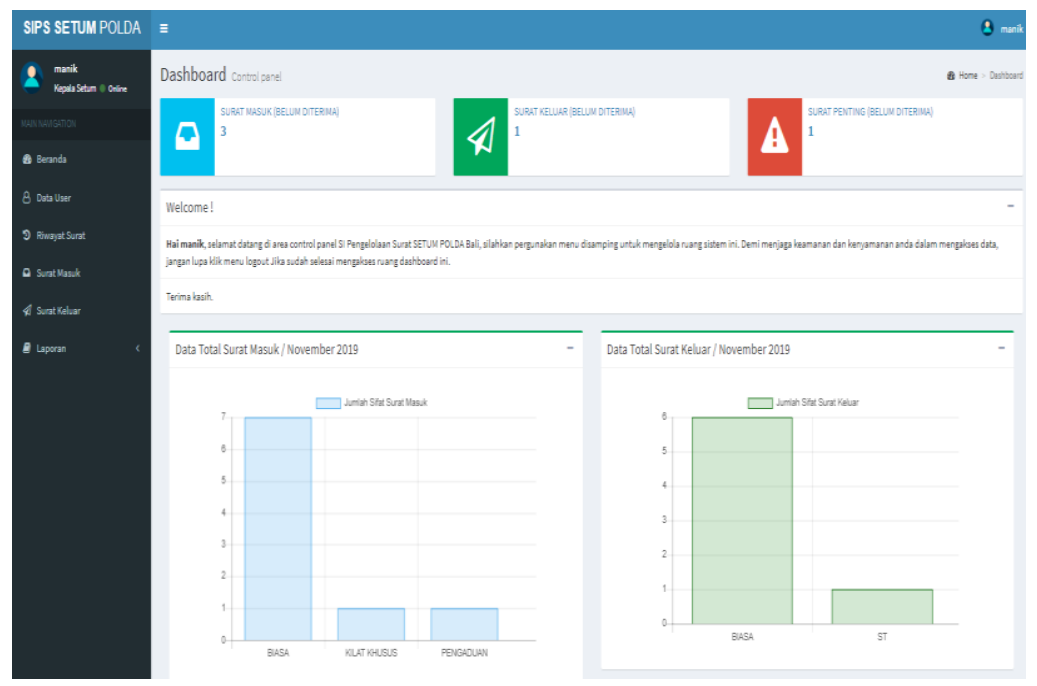

Gambar 5. Halaman Hak Akses Kepala Setum

Halaman Hak Akses Pegawai Setum

Halaman beranda Pegawai Setum merupakan halaman utama yang muncul ketika Pegawai Setum telah berhasil melakukan proses login yang kemudian akan menampilkan grafik total surat masuk dan surat 
keluar serta menampilkan pemberitahuan jumlah surat yang masuk dan keluar. Halaman ini, Pegawai Setum memiliki beberapa hak akses untuk mengolah data, seperti data master, riwayat surat, surat masuk, surat keluar serta laporan. Pada menu data master terdapat 2 sub menu yang terdiri dari data bagian dan sifat surat. Untuk menu laporan terdiri dari 4 sub menu, yaitu laporan surat masuk, laporan surat keluar, laporan disposisi surat masuk serta laporan grafik data surat. Halaman beranda Pegawai Setum dapat dilihat pada gambar 4.3 sebagai berikut.

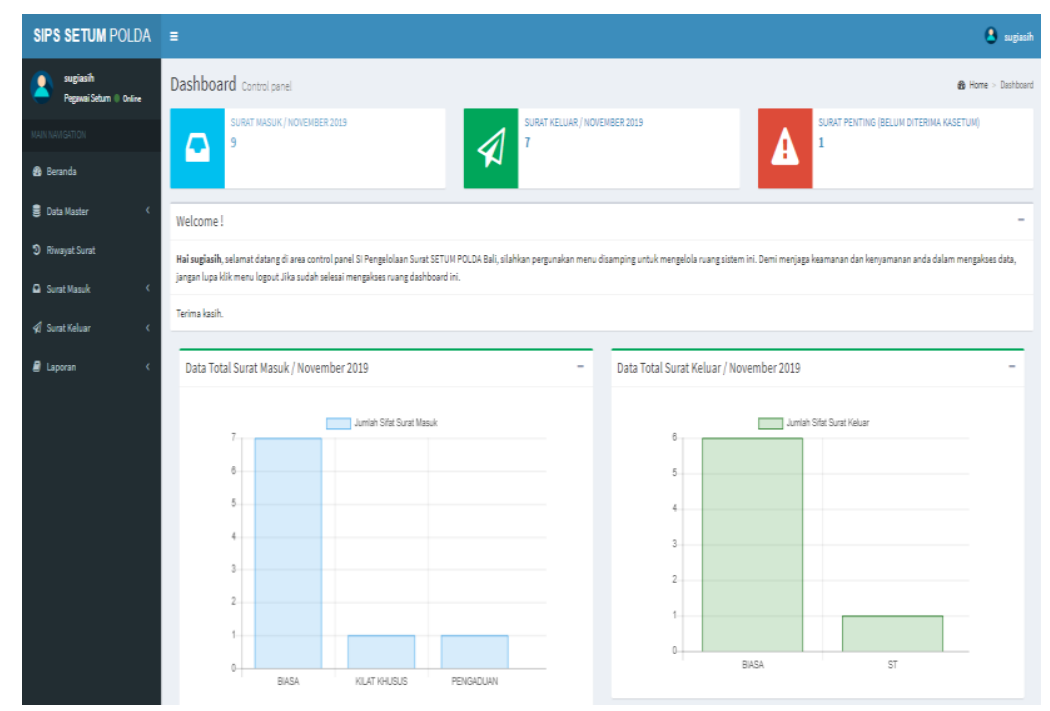

Gambar 6. Halaman Beranda Pegawai Setum

Halaman Hak Akses Pegawai Bagian

Halaman hak akses pegawai bagian pada gambar 4.81 merupakan halaman utama ketika pegawai bagian telah melalukan proses login terlebih dahulu. Pada halaman ini terdapat $4 \mathrm{menu}$, yaitu beranda, riwayat surat, data surat masuk dan surat keluar. Halaman hak akses Pegawai bagian, Pegawai bagian dapat melihat dan menerima data surat masuk pada menu surat masuk. Untuk membuat surat keluar, pegawai bagian dapat memilih menu surat keluar yang akan menampilkan sebuah form surat keluar.

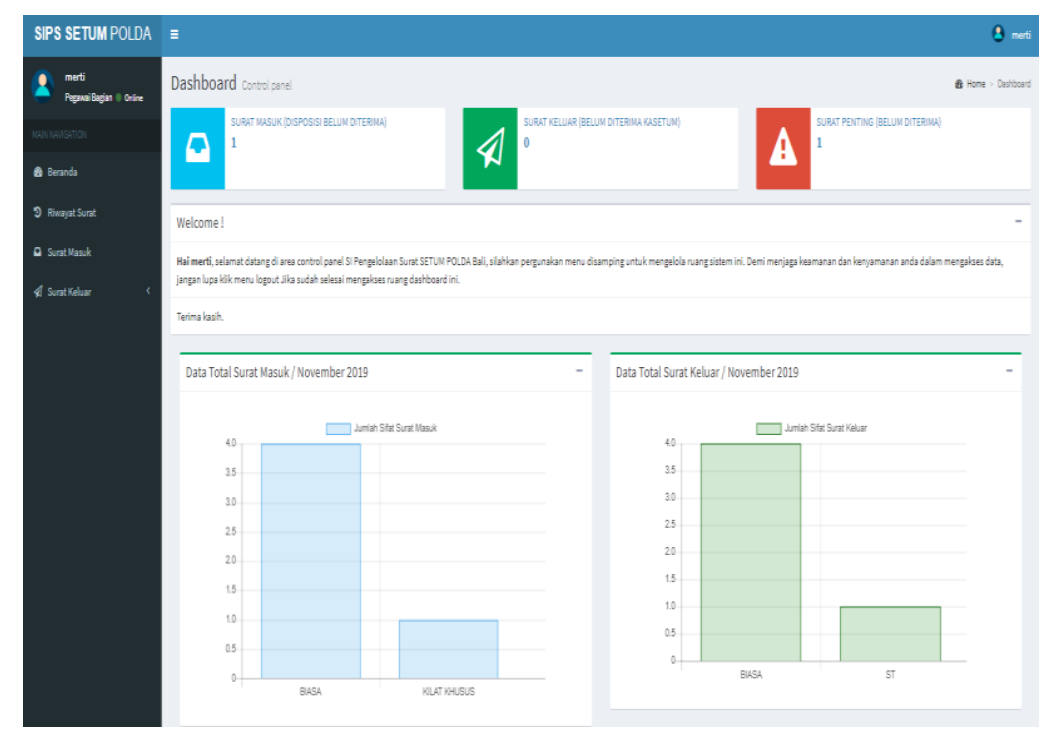

Gambar 7. Halaman Hak Akses Pegawai Bagian

Halaman Hak Akses Pengirim Surat

Halaman cek status surat merupakan tampilan yang muncul ketika pengirim surat menekan link cek surat pada halaman login. Pada halaman ini, terdapat sebuah kolom yang mewajibkan pengirim surat untuk mengisi nomor surat agar dapat melihat atau mengecek status surat berdasarkan surat yang dikirim. 


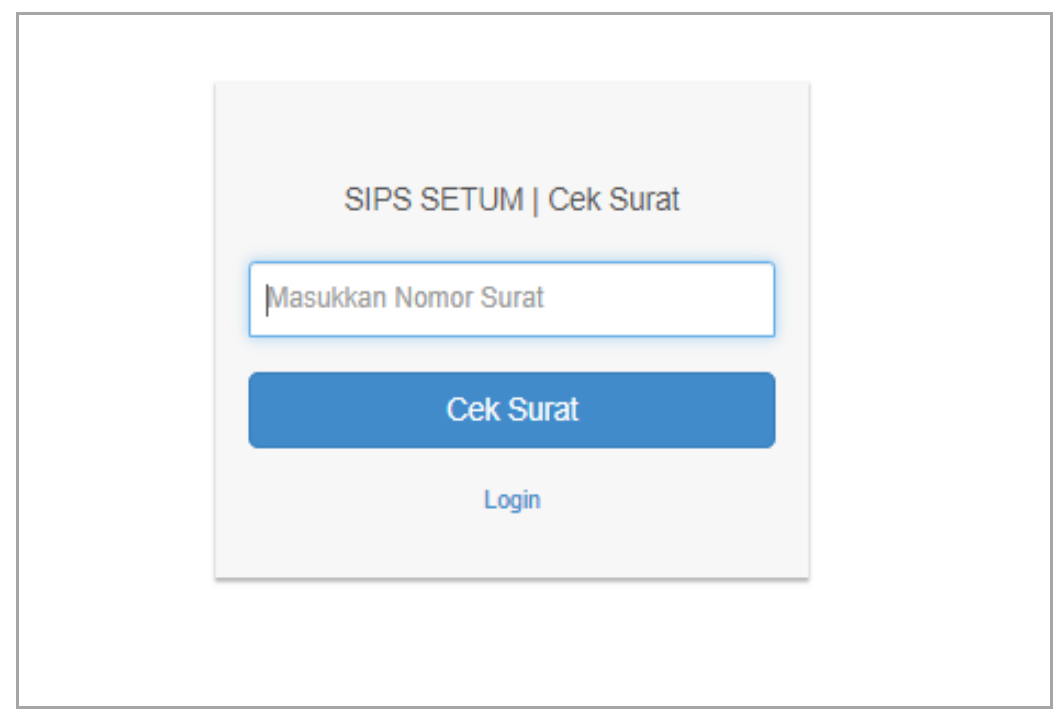

Halaman Master Data

Gambar 8. Halaman Cek Status Surat

1. Halaman Data user

Halaman data user merupakan halaman yang hanya dapat diakses oleh Kepala Setum. Halaman ini menampilkan seluruh data user yang ada pada instansi Setum Polda Bali. Halaman data user dapat dikelola oleh Kepala Setum dengan menambahkan, mengubah dan mencari seluruh data user yang akan ditampilkan dalam bentuk tabel.

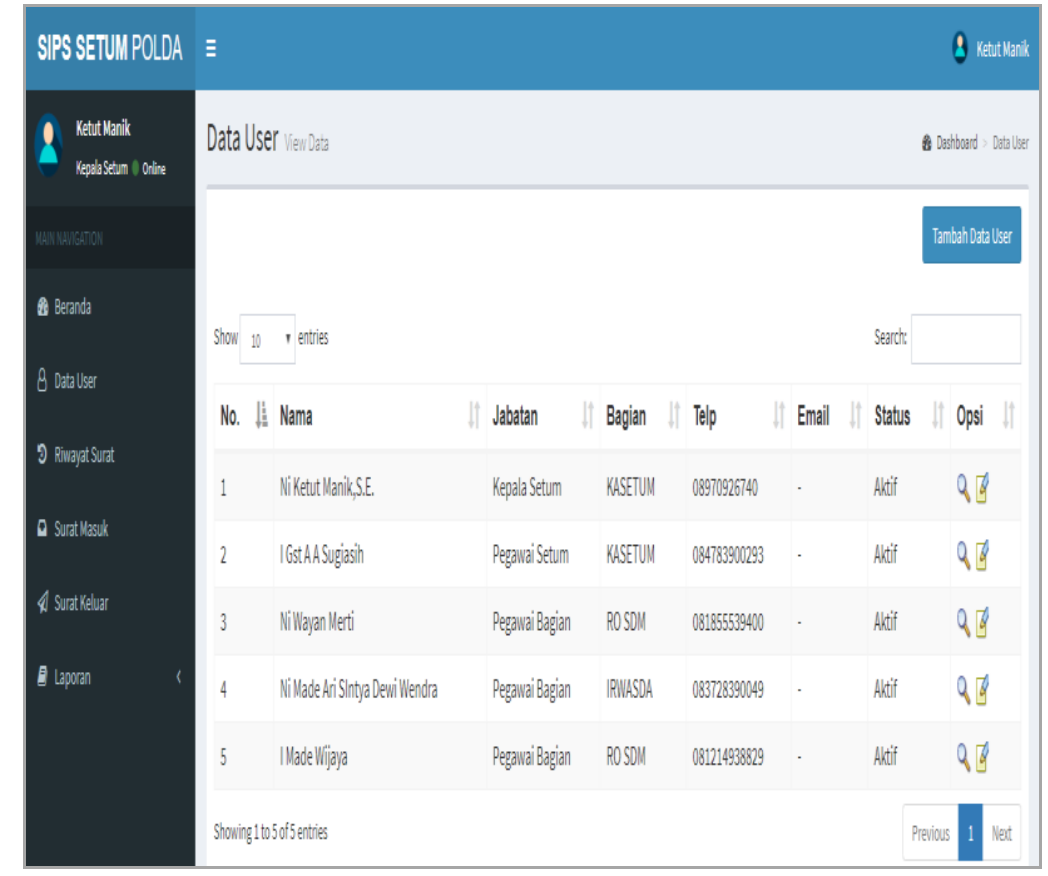

\section{Halaman Data Bagian}

Gambar 9. Halaman Data User

Halaman data bagian merupakan halaman yang muncul ketika Pegawai Setum memilih menu data master kemudian memilih data bagian. Halaman ini, menampilkan seluruh data bagian yang ada pada instansi Setum Polda Bali. Pada halaman ini, Pegawai Setum dapat menambahkan, mengubah dan mencari seluruh data bagian. Data bagian yang telah ditambahkan akan ditampilkan dalam bentuk tabel. 


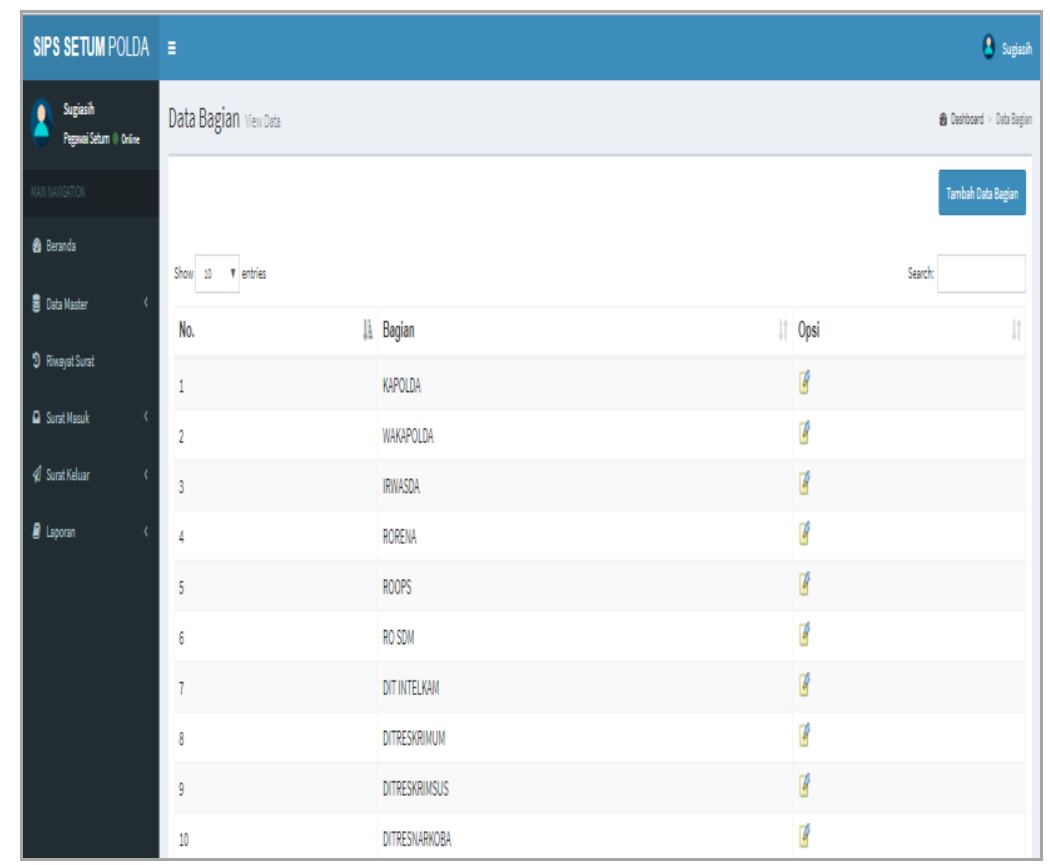

Gambar 10. Halaman Data Bagian

\section{Halaman Data Sifat Surat}

Halaman data sifat surat merupakan tampilan yang akan muncul ketika Pegawai Setum memilih data master kemudian memilih menu data sifat surat. Pada halaman ini, Pegawai Setum dapat mengolah data dengan menambahkan, mengubah dan mencari data sifat surat. Data sifat surat yang telah ditambahkan akan ditampilkan dalam bentuk tabel.

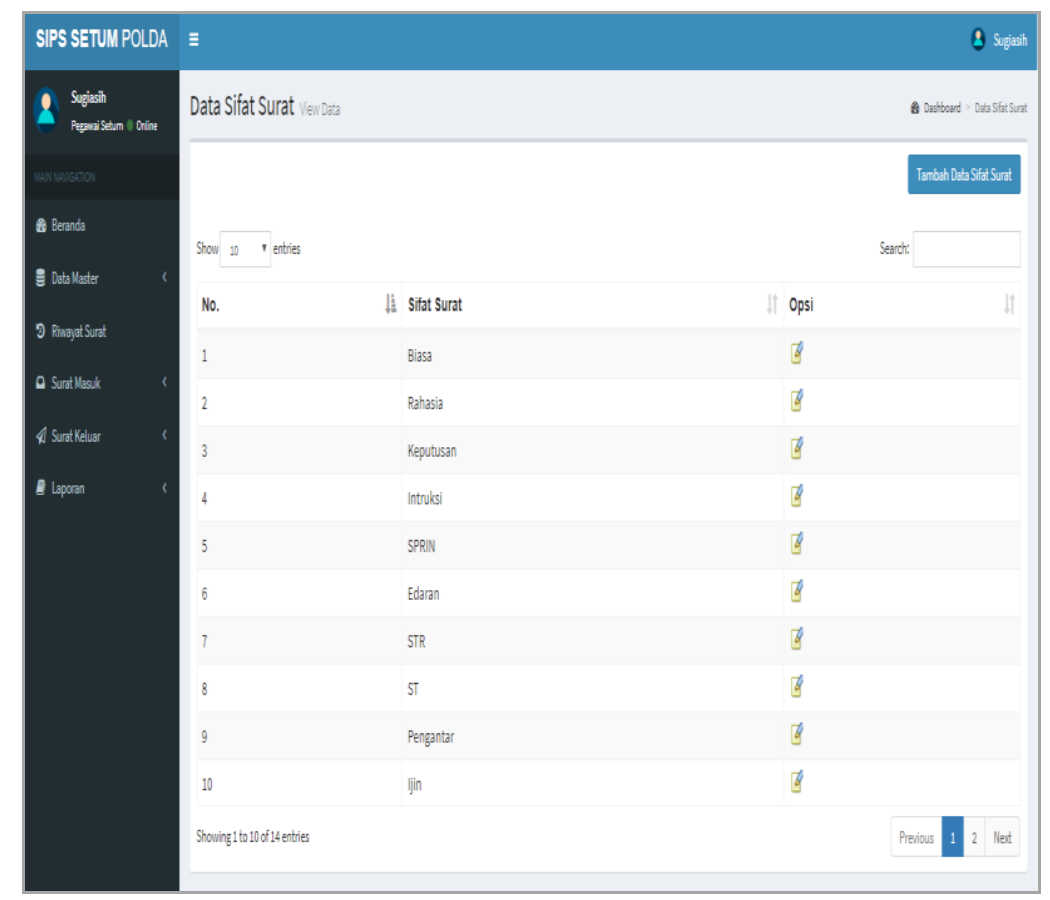

\section{Gambar 11. Halaman Data Sifat Surat}

Halaman Mengelola Surat Masuk

1. Halaman Surat Masuk

Halaman surat masuk merupakan halaman yang tampil ketika pegawai memilih menu surat masuk. Halaman ini, menampilkan seluruh data surat masuk dalam bentuk tabel. Halaman data surat masuk dapat diakses oleh Pegawai bagian, Pegawai Setum dan Kepala Setum. Pada halaman data surat masuk 
yang diakses oleh Pegawai Setum, Pegawai Setum dapat mengubah dan mengapus data surat masuk, sedangkan Pegawai bagian dan Kepala Setum hanya dapat melihat dan menerima surat masuk.

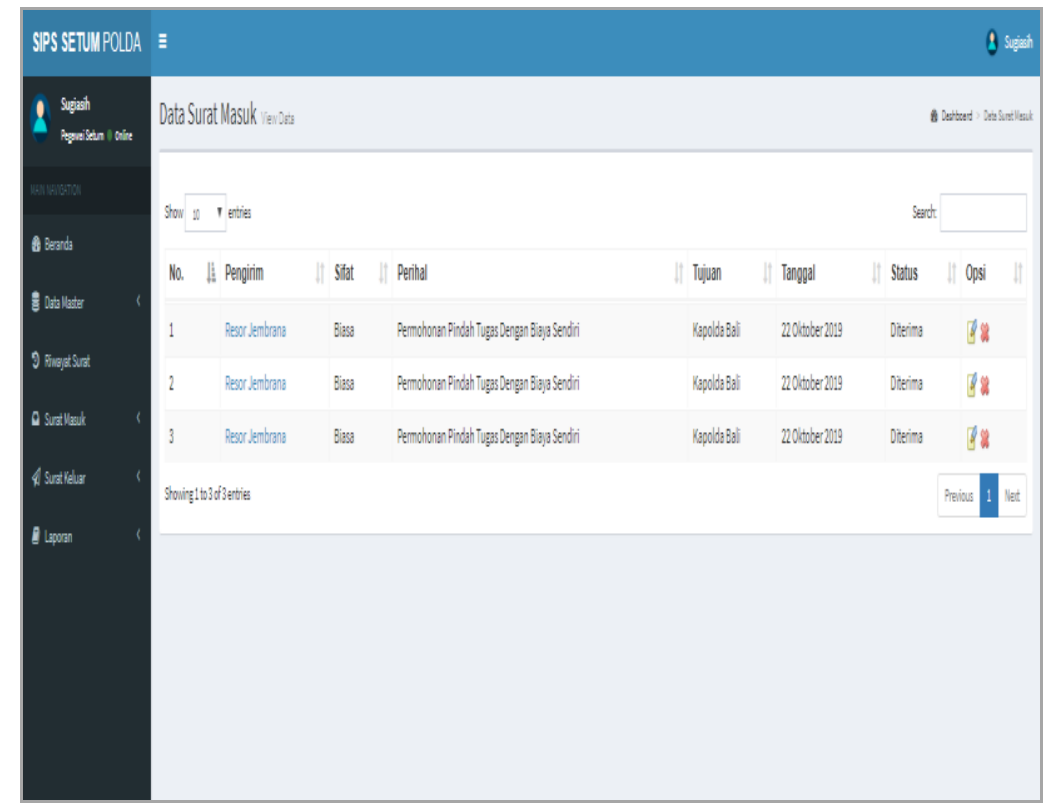

Gambar 12. Halaman Surat Masuk

\section{Halaman Terima Surat Masuk}

Halaman terima surat masuk merupakan halaman yang dapat diakses oleh Kepala Setum dan Pegawai bagian. Pada halaman ini, Kepala Setum dan Pegawai bagian dapat mengunduh berkas surat serta dapat menerima surat dengan menekan tombol terima. Halaman ini bertujuan untuk mengetahui status surat masuk bahwa data surat yang dikirim telah dibaca atau diterima.

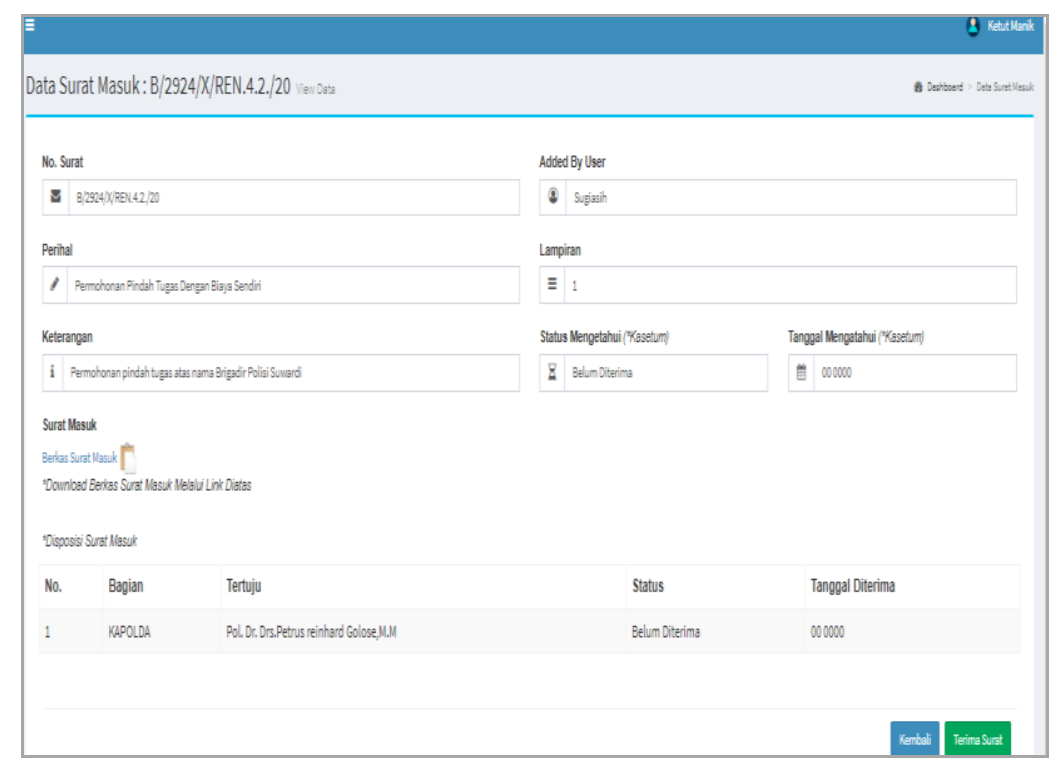

Gambar 13. Halaman Terima Surat Masuk

3. Halaman Cetak Disposisi

Halaman cetak disposisi merupakan halaman yang muncul ketika pengguna menekan link cetak disposisi. Saat pengguna menekan link tesebut, pengguna langsung diarahkan ke halaman baru yaitu halaman lembar disposisi. Pada halaman ini menampilkan beberapa pengaturan untuk mencetak lembar disposisi serta menampilkan hasil dari disposisi yang telah ditambahkan. 


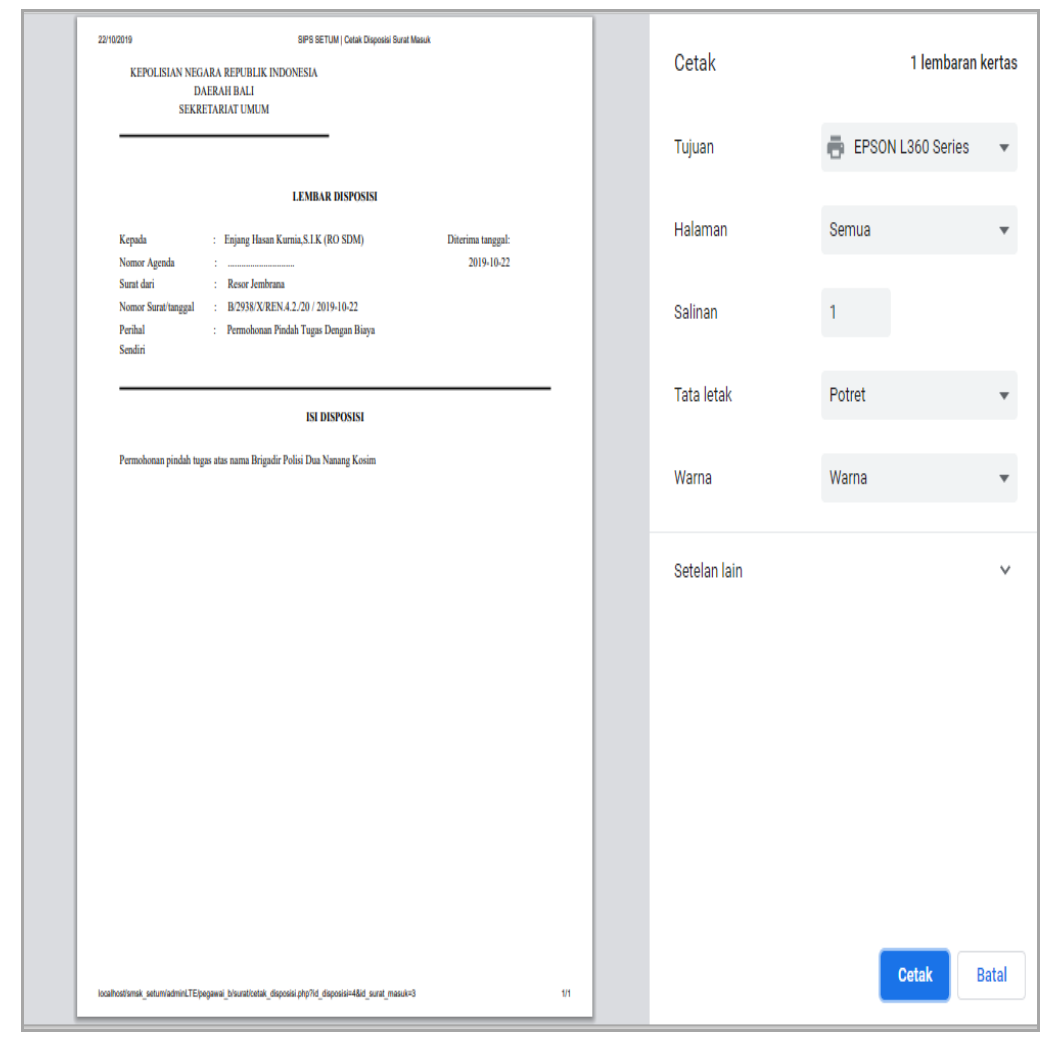

Gambar 14. Halaman Cetak Disposisi

Halaman Mengelola Surat Keluar

1. Halaman Surat Keluar

Halaman data surat keluar merupakan tampilan yang akan muncul ketika pengguna memilih data master dan kemudian memilih menu surat keluar. Halaman ini, menampilkan seluruh data surat keluar dalam bentuk tabel. Halaman data surat keluar dapat diakses oleh Pegawai bagian, Pegawai Setum dan Kepala Setum. Pada halaman data surat keluar yang diakses oleh Pegawai Setum dan Pegawai Bagian, pegawai dapat mengubah dan menghapus data surat keluar, sedangkan Kepala Setum hanya dapat melihat dan menerima surat keluar. Halaman surat keluar dapat dilihat pada gambar 15 berikut.

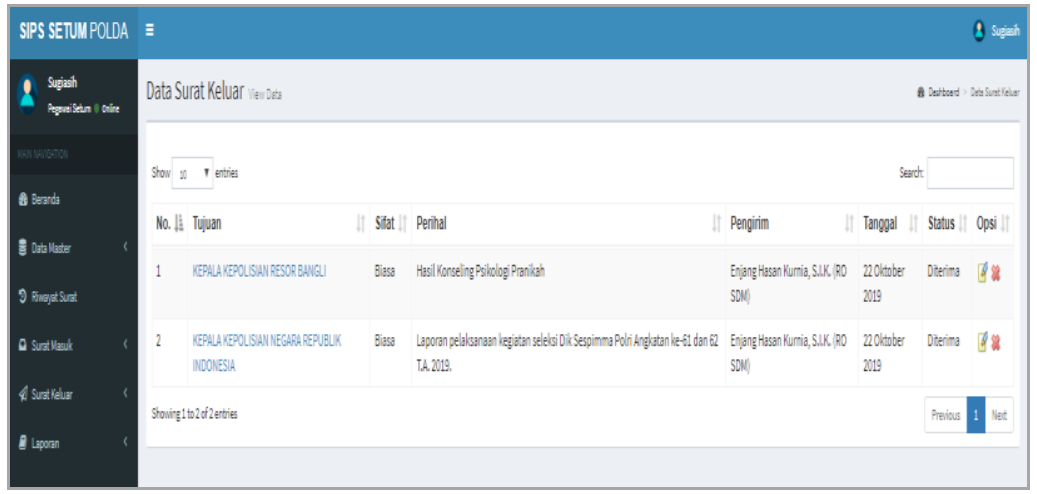

Gambar 15. Halaman Surat Keluar

\section{Halaman Terima Surat Keluar}

Halaman terima surat keluar pada gambar 4.52 merupakan halaman yang dapat dikelola oleh Kepala Setum. Halaman ini menampilkan data surat keluar yang diajukan oleh pegawai yang memerlukan persetujuan dari Kepala Setum. Kepala Setum dapat melihat isi dari surat dan memeriksa kebenaran surat. Apabila surat tersebut sudah benar maka Kepala Setum dapat menekan tombol terima surat yang menandakan bahwa surat tersebut sudah disetujui oleh Kepala Setum. 


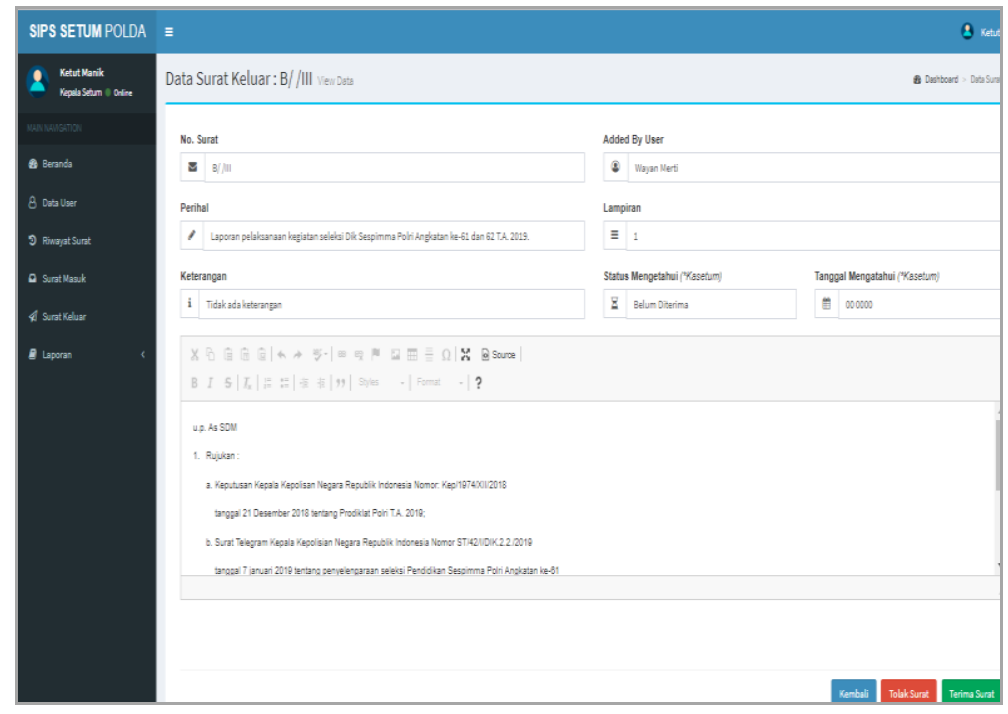

Gambar 16. Halaman Terima Surat Keluar

\section{Halaman Cetak Surat Keluar}

Halaman cetak surat keluar merupakan halaman yang muncul ketika pengguna menekan tombol cetak surat. Saat pengguna menekan tombol cetak, pengguna langsung diarahkan ke halaman baru yaitu halaman cetak surat keluar. Pada halaman cetak surat keluar, halaman ini menampilkan beberapa pengaturan untuk mencetak surat serta menampilkan hasil dari data surat keluar yang telah ditambahkan.

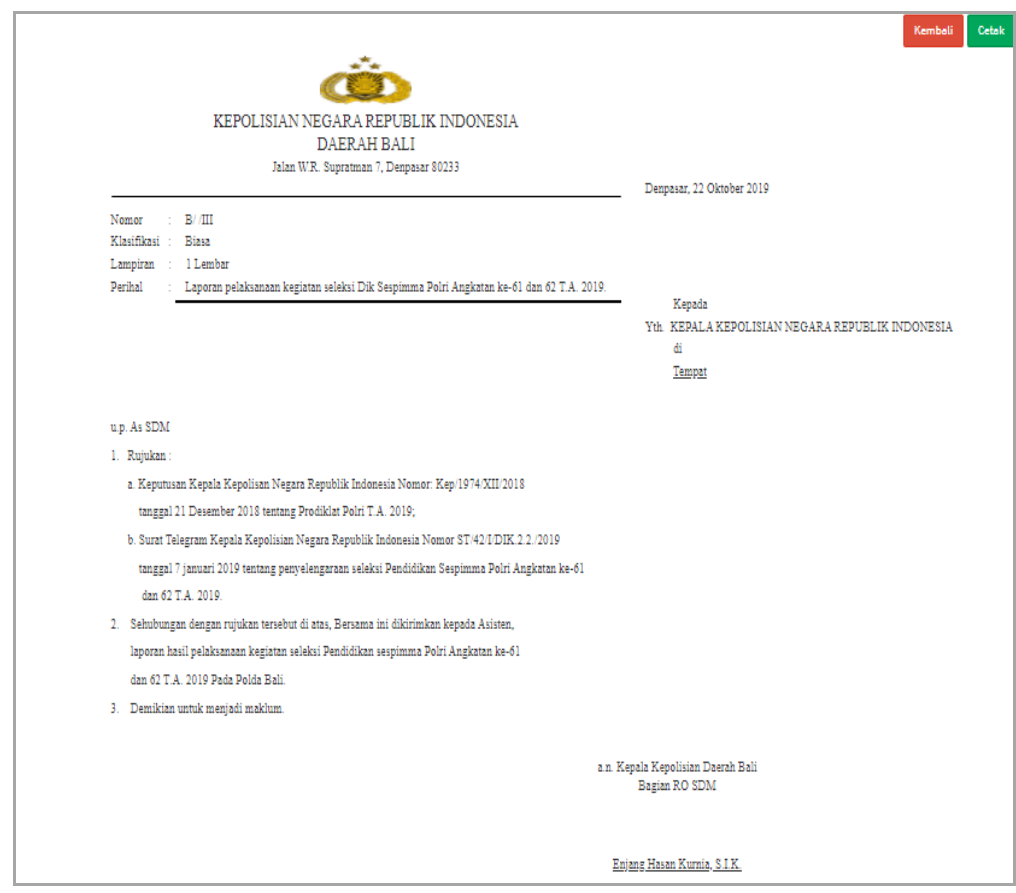

Gambar 17. Halaman Cetak Surat Keluar

Halaman Mengelola Laporan

1. Halaman Laporan Surat Masuk

Halaman laporan surat masuk merupakan halaman untuk mengelola laporan data surat masuk sesuai dengan periode yang ditentukan, serta dapat diakses oleh Pegawai Setum dan Kepala Setum. Untuk melihat hasil laporan surat masuk, pengguna dapat memilih bulan dan tahun yang ingin ditampilkan, selanjutnya pengguna dapat menekan tombol tampil kemudian akan tampil sebuah tabel data surat masuk pada halaman. 


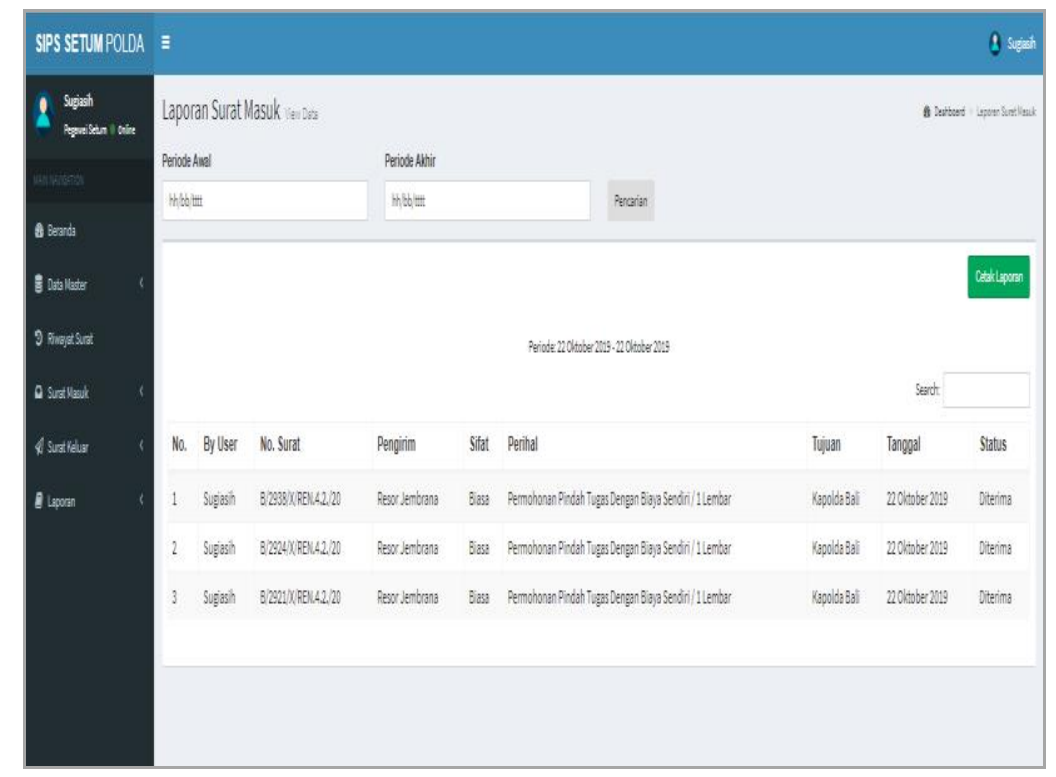

Gambar 18. Halaman Laporan Surat Masuk

\section{Halaman Laporan Surat Keluar}

Halaman laporan surat keluar merupakan halaman yang dapat diakses oleh Pegawai Setum dan Kepala Setum untuk mengelola laporan data surat keluar sesuai dengan periode yang ditentukan. Untuk melihat hasil laporan surat keluar, pengguna dapat memilih bulan dan tahun yang ingin ditampilkan, selanjutnya pengguna dapat menekan tombol pencarian kemudian akan tampil sebuah tabel data surat keluar.

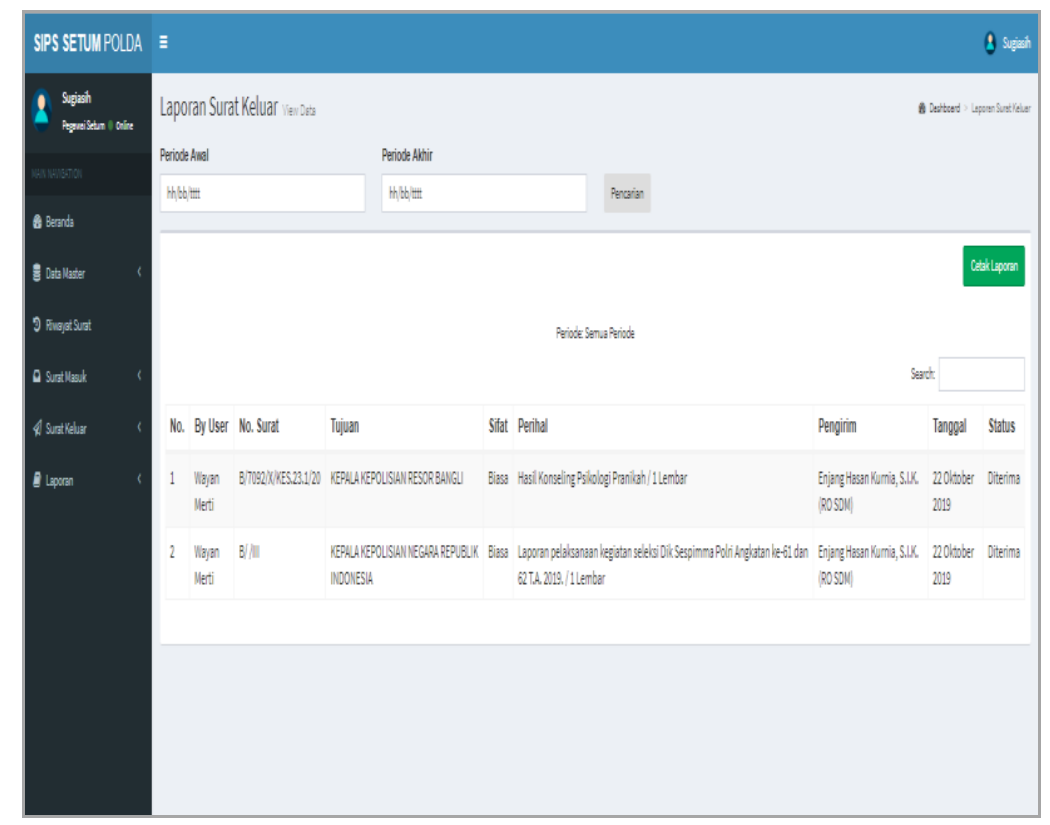

Gambar 19. Halaman Laporan Surat Keluar

3. Halaman Laporan Disposisi

Halaman laporan disposisi merupakan halaman yang dapat diakses oleh Pegawai Setum dan Kepala Setum untuk mengelola laporan data disposisi masuk sesuai dengan periode yang ditentukan. Untuk melihat hasil laporan disposisi, pengguna dapat memilih bulan dan tahun yang ingin ditampilkan, selanjutnya pengguna dapat menekan tombol pencarian kemudian akan tampil sebuah table data disposisi masuk pada halaman. 


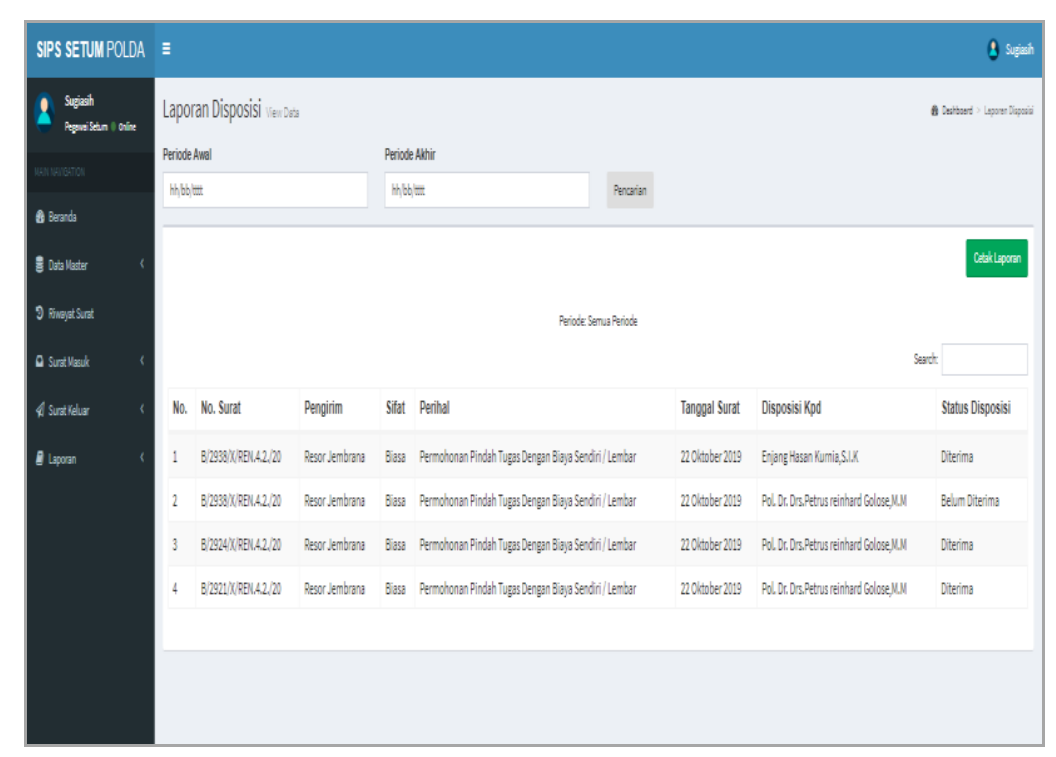

Gambar 20. Halaman Laporan Disposisi Masuk

4. Halaman Laporan Grafik Keseluruhan

Halaman laporan grafik data surat merupakan halaman yang menampilkan seluruh data surat masuk dan surat keluar dalam bentuk grafik berdasarkan dengan periode yang ditentukan. Halaman Laporan grafik data surat dapat diakses oleh Pegawai Setum dan Kepala Setum. Untuk melihat hasil laporan grafik data surat, pengguna dapat memilih bulan dan tahun yang ingin ditampilkan, selanjutnya pengguna dapat menekan tombol tampil kemudian akan tampil sebuah grafik jumlah surat masuk dan jumlah surat keluar.

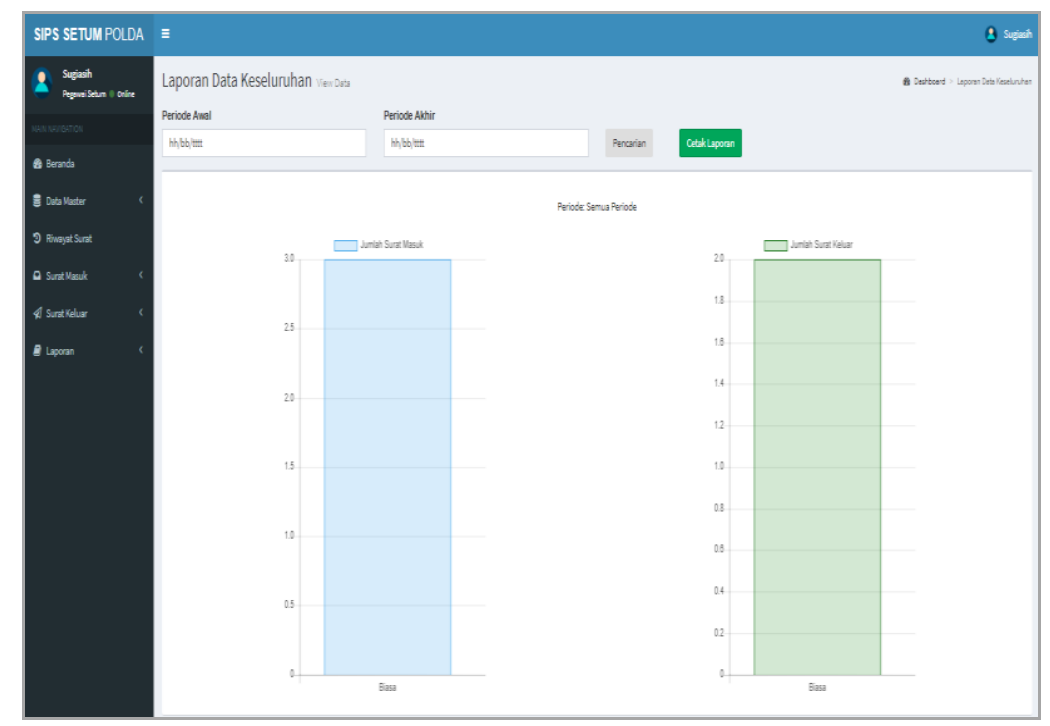

Gambar 21. Halaman Laporan Grafik Surat

\section{Simpulan dan saran}

Berdasarkan penelitian yang dilakukan pada Setum Polda Bali dengan menganalisis, merancang, membangun dan melakukan pengujian sistem, maka dapat diperoleh kesimpulan yaitu, pada penelitian yang dilakukan pada Setum Polda Bali telah berhasil dilakukan, hal tersebut dibuktikan dengan adanya sistem informasi pengelolaan surat masuk dan surat keluar pada Setum Polda Bali sudah mampu menyelesaikan proses pengelolaan surat dengan efektif serta efisien dalam penyampaian dan pencarian informasi surat serta dengan dibangunnya sistem informasi pengelolaan surat masuk dan surat keluar berbasis website ini, Setum Polda Bali menjadi terbantu dalam pelaksanaan proses pengelolaan dan pelaporan surat serta mempermudah pencarian data dan penyampaian informasi surat.. 


\section{Daftar Rujukan}

Kristanto, A. 2018. Perancangan Sistem Informasi dan Aplikasinya (Edisi Revisi). Yogyakarta: PENERBIT GAVA MEDIA.

Marisa, F. 2017. Web Programming (Client Side and Server Side). Yogyakarta: Deepublish.

Suryani 2014. Korespondensi Bahasa Indonesia. Yogyakarta: Graha Ilmu.

Raharjo, B. 2016. Pemerograman WEB (HTML, PHP \& MySQL) Edisi 3,. Bandung: Modula. 